This report was prepared as an account of work sponsored by an agency of the United States Government. Neither the United States Government nor any agency therteof, nor any of their employees, makes any warranty, express or implied, or assumes any legal liability or responsibility for the accuracy, completeness, or usefulness of any information, apparatus, product, or process disclosed, or represents that its use would not infringe privately owned rights. Reference herein to any specific commercial product, process, or service by trade name, trademark, manufacturer, or otherwise does not necessarily constitute or imply its endorsement, recommendation, or favoring by the United States Government or any agency thereof. The views and opinions of authors expressed herein do not necessarily state or reflect those of the United States Government or any agency thereof.

\title{
ADVANCED MATERIALS AND ELECTROCHEMICAL PROCESSES IN HIGH-TEMPERATURE SOLID ELECTROLYTES
}

\author{
J. L. Bates \\ L. A. Chick \\ G. E. Youngblood \\ W. J. Weber
}

October 1990

Semiannual Progress Report

Fossil Energy AR\&TD Materials Program

Oak Ridge National Laboratory

Oak Ridge, Tennessee

Work supported by the

U.S. Department of Energy

under Contract DE-AC06-76RLO 1830

Pacific Northwest Laboratory

Richland, Washington 99352 


\title{
PNL-1 (A) - ADVANCED MATERIALS AND ELECTROCHEMICAL PROCESSES IN HIGH-TEMPERATURE SOLID ELECTROLYTES
}

\author{
J. L. Bates, L. A. Chick, G. E. Youngblood and W. J. Weber \\ Pacific Northwest Laboratory \\ Post Office Box 999 \\ Richland, Washington 99352
}

\section{INTRODUCTION}

The purpose of this research and development effort is to: (1) identify, develop, and demonstrate advanced materials for use as advanced electrodes, current interconnections and electrolytes in hightemperature solid- electrolyte electrochemical cells, and (2) develop an understanding of the synergistic effects of materials properties, structures and compositions on electrochemical processes associated with high-temperature solid-electrolyte electrochemical cells.

\section{BACKGROUND}

Fuel cells are emerging as an attractive, clean and efficient technology for the direct conversion of fossil fuel to electrical energy. High-temperature solid oxide fuel cells (SOFCs) have seen promising major advancements in recent years. Recently the technology of high-temperature solid electrolytes is also being considered for other advanced electrochemical processes, including chemical synthesis, oxygen pumps, sensors, chemical separation, etc.

State-of-the-art solid oxide electrolyte concepts are based on an $\mathrm{Y}_{2} \mathrm{O}_{3}$ stabilized $\mathrm{ZrO}_{2}$ electrolyte with a $\mathrm{La}(\mathrm{Sr}) \mathrm{MnO}_{3}$ air electrode, a $\mathrm{ZrO}_{2} / \mathrm{Ni}(\mathrm{CO})$ cermet fuel electrode, and $\mathrm{La}(\mathrm{Mg}$ or Sr$) \mathrm{CrO}_{3}$ as the current interconnection. These current materials do not meet state-of-the-art SOFC requirements because of materials interactions, inadequate electrical and thermal properties, incompatible electrical/polarization interface characteristics, and the complex series of fabrication and processing steps required. To eliminate or minimize these limitations of state-of-the-art SOFCs and for application to other high-temperature solid-electrolyte technologies, advanced electrode, electrolyte, and interconnection materials coupled with new synthesis and fabrication methods are required to improve electrochemical cell performances and lower costs. As high-temperature electrochemical concepts are advancer, nev: materials with the desired electrical, thermal, and electrochemical

\footnotetext{
aPacific Northwest Laboratory is operated by Battelle Memorial Institute for the U.S. Department of Energy linder Contract DE-ACO6-76RLO 1830.
} 
properties will also be required. Introduction of these advanced materials will necessitate development of appropriate synthesis and fabrication methods. An understanding of the electrochemical processes associated with electrochemical cells, such as SOFCs, can provide direction for R\&D leading to new and improved materials and to the broader application, improved performance and favorable economics of high-temperature solid-electrolyte electrochemical technologies.

\section{APPROACH}

The scope of this investigation includes: (1) determination of electrical transport, thermal and electrochemical properties leading to an understanding of the effects of microstructure, phase equilibria, oxygen partial pressure, additives, synthesis and fabrication on these properties; (2) investigation of the synthesis and fabrication of these advanced oxide materials; and (3) application of new analytical techniques using complex impedance coupled with conventional electrochemical methods to study the electrochemical processes and behavior of materials for SOFCs and other hightemperature-electrolyte electrochemical processes.

The current study of materials and electrochemical processes emphasizes:

- mixed ionic-electronic conducting oxides of $\mathrm{ZrO}_{2}\left(\mathrm{HfO}_{2}\right)-\mathrm{RE}_{\mathrm{x}} \mathrm{O}_{\mathrm{y}}-\mathrm{MO}_{\mathrm{z}}$ systems as advanced electrode materials to promote enhanced electrode/electrolyte charge transfer and compatible fabrication processes,

- advanced compositions of $\mathrm{La}\left(\mathrm{M}^{\prime}\right)\left(\mathrm{Cr}, \mathrm{M}^{n}\right) \mathrm{O}_{3}$ as electronically conducting current interconnections, having improved thermal compatibility, higher electrical conductivity and enhanced air sinterability for ease of fabrication,

- the electrochemical processes of high-temperature solid electrolytes and their electrodes and interconnections, specifically as applied to materials interfaces and electrochemical reactions, with initial emphasis on SOFC systems.

\section{DISCUSSION OF CURRENT ACTIVITIES}

\section{Materials as Anode Fuel Electrodes}

The anode, or fuel electrode, of the SOFC operates at very low oxygen partial pressures. Present state-of-the-art SOFC anodes are porous $\mathrm{Ni} / \mathrm{Y}_{2} \mathrm{O}_{3}$ stabilized $\mathrm{ZrO}_{2}$ composites bonded to the $\mathrm{Y}_{2} \mathrm{O}_{3}$ stabilized $\mathrm{ZrO}_{2}$ electrolyte and current interconnection. However, because of inherent differences in the thermal expansion coefficients of metals and the oxide electrolyte and intcrconnection, it is 
advantageous to replace the metal-uxide composite with an all ceramic electrode material that can be fabricated in air. The approach is to investigate mixed ionic-electronic conducting oxides of $\mathrm{RE}_{\mathrm{x}} \mathrm{O}_{\mathrm{y}}-\mathrm{ZrO}_{2}\left(\mathrm{HiO}_{2}\right)-\mathrm{MO}_{z}$ systems $\left(\mathrm{Y}_{2} \mathrm{O}_{3}\right.$ is included with $\left.\mathrm{RE}_{\mathrm{x}} \mathrm{O}_{\mathrm{y}}\right)$ that can be fabricated in air, and then be modified in situ into a high-electronic conductor in the highly-reducing environment of the fuel, while still retaining thermal-mechanical compatibility with the $\mathrm{Y}_{2} \mathrm{O}_{3}$ stabilized $\mathrm{ZrO}_{2}$ electrolyte. The two oxide systems currently being investigated are the $\mathrm{Y}_{2} \mathrm{O}_{3}-\mathrm{ZrO}_{2}-\mathrm{TiO}_{2}$ and $\mathrm{Y}_{2} \mathrm{O}_{3}-\mathrm{ZrO}_{2}-\mathrm{CeO}_{2}$ systems.

The study of the (0.1) $\mathrm{Y}_{2} \mathrm{O}_{3}-(0.9-\mathrm{x}) \mathrm{ZrO}_{2}-(\mathrm{x}) \mathrm{CeO}_{2}$ system was reported previously ${ }^{1-3}$ and will be reviewed only briefly for comparison with the $(0.1) \mathrm{Y}_{2} \mathrm{O}_{3}-(0.9-\mathrm{x}) \mathrm{ZrO}_{2}-(\mathrm{x}) \mathrm{TiO}_{2}$ systems.

\section{$\underline{\mathrm{Y}}_{2} \underline{\mathrm{O}}_{3}-\underline{\mathrm{ZrO}}_{2}-\underline{\mathrm{TiO}}_{2}$ System}

Compounds of $(0.1) \mathrm{Y}_{2} \mathrm{O}_{3}-(0.9-\mathrm{x}) \mathrm{ZrO}_{2}-(\mathrm{x}) \mathrm{TiO}_{2}$ with $\mathrm{x}=0.0,0.25,0.45,0.65$, and 0.90 were prepared by the Glycine-Nitrate process, ${ }^{4}$ in conjunction with precipitated $\mathrm{TiO}_{2}$ from alkoxide hydrolysis. The powdered ash from this combustion synthesis process was calcined in air at $923 \mathrm{~K}$ for $5 \mathrm{~h}$, sonicated in a slurry of hexane with $0.02 \%$ fish oil, and dried. Rectangular samples of each compound were isostatically pressed at $139 \mathrm{MPa}$ and sintered at $1773 \mathrm{~K}$ for $12 \mathrm{~h}$.

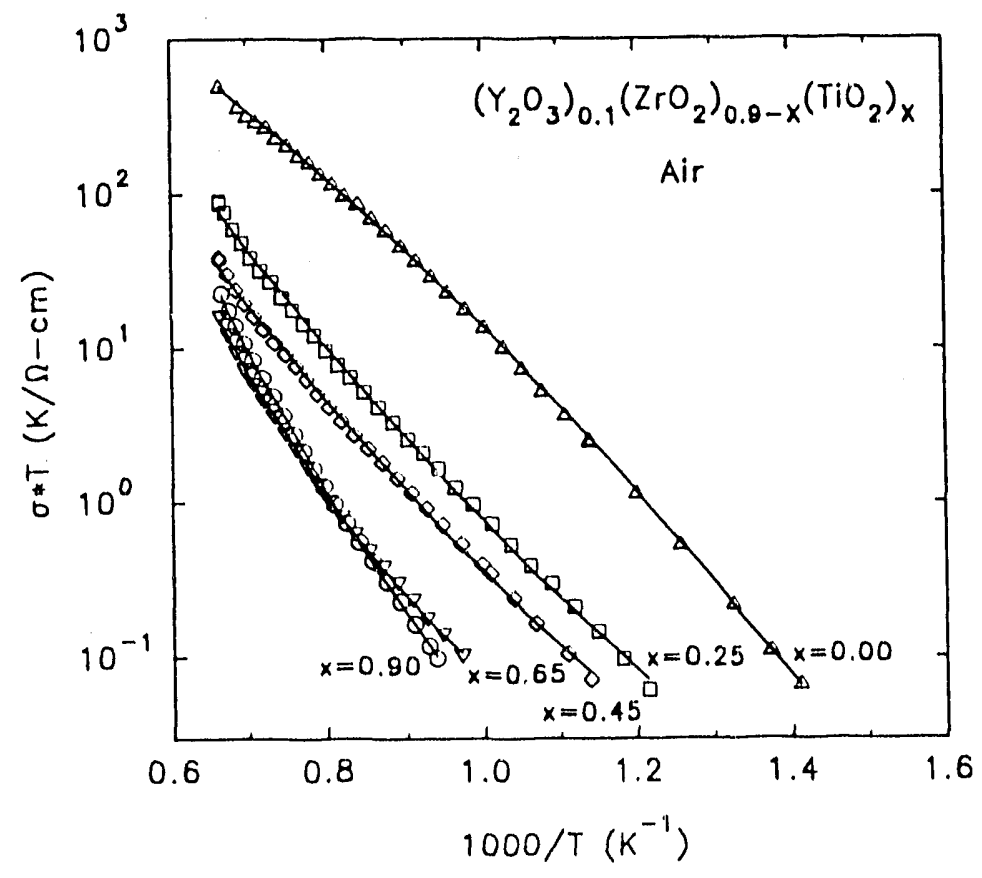

Fig. 1. Electrical conductivity of $(0.1) \mathrm{Y}_{2} \mathrm{O}_{3}^{-(0.9-x)} \mathrm{ZrO}_{2}-(\mathrm{x}) \mathrm{TiO}_{2}$ in Air. 
The electrical conductivity $(\sigma)$ was measured using a four-probe dc (pulse) technique with platinum knife-edge contacts. Measurements were made in air over the temperature range from 800 to $1500 \mathrm{~K}$ and in an $\mathrm{Ar}-4 \% \mathrm{H}_{2}$ atmosphere over the temperature range from 300 to $1373 \mathrm{~K}$. Measurements were made both on heating and cooling in both atmospheres. The oxygen partial pressure at $1373 \mathrm{~K}$ for the $\mathrm{Ar}-4 \% \mathrm{H}_{2}$ al mosphere was approximately $10^{-10}$ pascal $\left(10^{-15} \mathrm{~atm}\right.$.).

$\underline{\mathrm{Y}}_{2} \mathrm{O}_{3}-\mathrm{ZrO}_{2}-\mathrm{TiO}_{2}$ Conductivity in Air. The electrical conductivity results for $(0.1) \mathrm{Y}_{2} \mathrm{O}_{3}-(0.9-\mathrm{x}) \mathrm{ZrO}_{2}-(\mathrm{x}) \mathrm{TiO}_{2}$ in air are summarized in Figure 1, with the data plotted as $\log (\sigma \mathrm{T})$ versus $1 / \mathrm{T}$. In air, the electrical conductivity decreases with increasing mole fraction of $\mathrm{TiO}_{2}$ substitution for $\mathrm{ZrO}_{2}$. There is a slight crossover in behavior for the $\mathrm{x}=0.65$ and $\mathrm{x}=0.9$ compounds, with the $x=0.9$ compound showing slightly higher conductivity above $1300 \mathrm{~K}$.

The electrical conductivity is assumed to be nearly $100 \%$ ionic for these compositions in air. Consequently, the ionic conductivity, $\sigma_{\text {ion }}$, can be given by the expression of Tuller and Nowick ${ }^{5}$ :

$$
\sigma_{\text {ion }}=\left(\sigma_{0} / T\right) \exp \left(-E_{\mathrm{m}} / \mathrm{kT}\right)
$$

where $\sigma_{o}$ is a charge-carrier and material dependent constant, $E_{m}$ is the activation energy for ionic migration, $\mathrm{k}$ is the Boltzmann constant, and $\mathrm{T}$ is the absolute temperature. The activation energies for ionic conduction were determined from the plots of $\log (\sigma \mathrm{T})$ versus $1 / \mathrm{T}$ in Figure 1 and are given in Table 1. The activation energies for ionic conduction in air for the $(0.1) \mathrm{Y}_{2} \mathrm{O}_{3}-(0.9-\mathrm{x}) \mathrm{ZrO}_{2}-(\mathrm{x}) \mathrm{TiO}_{2}$ system increase with increasing $\mathrm{TiO}_{2}$ substitution, which suggests decreased mobility as a result of the $\mathrm{TiO}_{2}$ substitution. The overall decreased conductivity with substitution of $\mathrm{TiC}_{2}$ for $\mathrm{ZrO}_{2}$ is due to both the increases in activation energy and an initial decrease in the number of oxygen vacancies available for ionic conduction, as suggested by the decrease in $\log \left(\sigma_{0}\right)$ for $x=0.25$ and $x=0.45$ in Table 1.

$\underline{\mathrm{Y}}_{2} \mathrm{O}_{3}-\mathrm{ZrO}_{2}-\mathrm{TiO}_{2}$ Conductivity in $4 \%$ Hydrogen. Prior to electrical conductivity measurements in the $\mathrm{Ar}-4 \% \mathrm{H}_{2}$ atmosphere, all the test specimens were equilibrated for $6 \mathrm{~h}$ in $\mathrm{Ar}-4 \% \mathrm{H}_{2}$ at $1273 \mathrm{~K}$. The high-temperature $(T>625 \mathrm{~K})$ electrical conductivity results for the $(0.1) \mathrm{Y}_{2} \mathrm{O}_{3}-(0.9-\mathrm{x}) \mathrm{ZrO}_{2}-(\mathrm{x}) \mathrm{TiO}_{2}$ specimens in the $\mathrm{Ar}-4 \% \mathrm{H}_{2}$ atmosphere are summarized in Figure 2 as $\log (\sigma \mathrm{T})$ versus $1 / \mathrm{T}$. The electrical conductivity in $\mathrm{Ar}-4 \% \mathrm{H}_{2}$ increases with increasing mole fraction of $\mathrm{TiO}_{2}$ substitution for $\mathrm{ZrO}_{2}$. This is believed to be due to changes in the transport characteristic from ionic to mixed ionic and electronic conduction with increasing $\mathrm{TiO}_{2}$ content. The electrical conductivity of the $(0.1) \mathrm{Y}_{2} \mathrm{O}_{3}-(0.9) \mathrm{ZrO}_{2}$ composition did not change under the reducing condition, which is consistent with known stability of this material over a wide range of oxygen partial pressures. 
Table 1. Activation Energies, $\mathrm{E}_{\mathrm{m}}$, and Values of $\log \left(\sigma_{\mathrm{o}}\right)$ Determined for the $(0.1) \mathrm{Y}_{2} \mathrm{O}_{3}-(0.9-\mathrm{x}) \mathrm{ZrO}_{2}-(\mathrm{x}) \mathrm{TiO}_{2}$ System in Air and $\mathrm{Ar}-4 \% \mathrm{H}_{2}$.

\begin{tabular}{|c|c|c|c|c|}
\hline Mole $\% \mathrm{TiO}_{2}$ & \multicolumn{2}{|c|}{$E_{m}(e V)$} & \multicolumn{2}{|c|}{$\log \sigma_{0}(\mathrm{~K} / \mathrm{n}-\mathrm{cm})$} \\
\hline $\mathrm{x}$ & Air & $4 \% \mathrm{H}_{2}$ & Air & $4 \% \mathrm{H}_{2}$ \\
\hline 0.00 & 1.01 & 1.03 & 6.16 & 6.28 \\
\hline 0.25 & 1.11 & 0.45 & 5.51 & 4.20 \\
\hline 0.45 & 1.11 & 0.36 & 5.19 & 4.28 \\
\hline 0.65 & 1.42 & 0.13 & 5.82 & 4.34 \\
\hline 0.90 & 1.69 & 0.09 & 6.93 & 4.98 \\
\hline
\end{tabular}

The activation energies determined from the slope of the $\log (\sigma \mathrm{T})$ versus $1 / \mathrm{T}$ data in Figure 2 are also given in Table 1. The measured decrease in activation energies is also consistent with a change from ionic conduction to predominantly electronic conduction. The decrease in $\log \left(\sigma_{0}\right)$ given in Table 1 also suggests a step decrease in charge carrier concentration with the initial addition of $\mathrm{TiO}_{2}$ under the $4 \% \mathrm{H}_{2}$ reducing conditions. It is believed at this point that the $\mathrm{x}=0.25$ and $\mathrm{x}=0.45$ specimens have a mixed mode conductivity under the $\mathrm{Ar}-4 \% \mathrm{H}_{2}$ reducing conditions, while the conductivity in the $x=0.65$ and $x=0.90$ specimens is predominantly electronic in nature.

\section{Comparison $\mathrm{Y}_{2} \mathrm{O}_{3}-\mathrm{ZrO}_{2}-\mathrm{TiO}_{2}$ with $\mathrm{Y}_{2} \mathrm{O}_{3}-\mathrm{ZrO}_{2}-\mathrm{CeO}_{2}$}

The electrical conductivities of $(0.1) \mathrm{Y}_{2} \mathrm{O}_{3}-(0.9-\mathrm{x}) \mathrm{ZrO}_{2}-(\mathrm{x}) \mathrm{TiO}_{2}$ in air are lower than the electrical conductivities for $(0.1) \mathrm{Y}_{2} \mathrm{O}_{3^{-}}(0.9-\mathrm{x}) \mathrm{ZrO}_{2^{-}}(\mathrm{x}) \mathrm{CeO}_{2}$ (see Figure 3 and 4). In air, the electrical conductivities of both the $\mathrm{CeO}_{2}$ and $\mathrm{TiO}_{2}$ systems are assumed to be rearly $100 \%$ ionic. The continuing decrease in electrical conductivity of $(0.1) \mathrm{Y}_{2} \mathrm{O}_{3}-(0.9-\mathrm{x}) \mathrm{ZrO}_{2}-(\mathrm{x}) \mathrm{TiO}_{2}$ is indicative of a decreasing number of oxygen ion vacancies. $\mathrm{TiO}_{2}$ does not substitute for $\mathrm{ZrO}_{2}$ or $\mathrm{Y}_{2} \mathrm{O}_{3}$ to retain the fluorite lattice, therein decreasing the number of oxygen ion vacancies required for ionic conduction. For $(0.1) \mathrm{Y}_{2} \mathrm{O}_{3}-(0.9-\mathrm{x}) \mathrm{ZrO}_{2}-(\mathrm{x}) \mathrm{CeO}_{2}$, the substitution of $\mathrm{CeO}_{2}$ for $\mathrm{Y}_{2} \mathrm{O}_{3}$ or $\mathrm{ZrO}_{2}$ results in a 


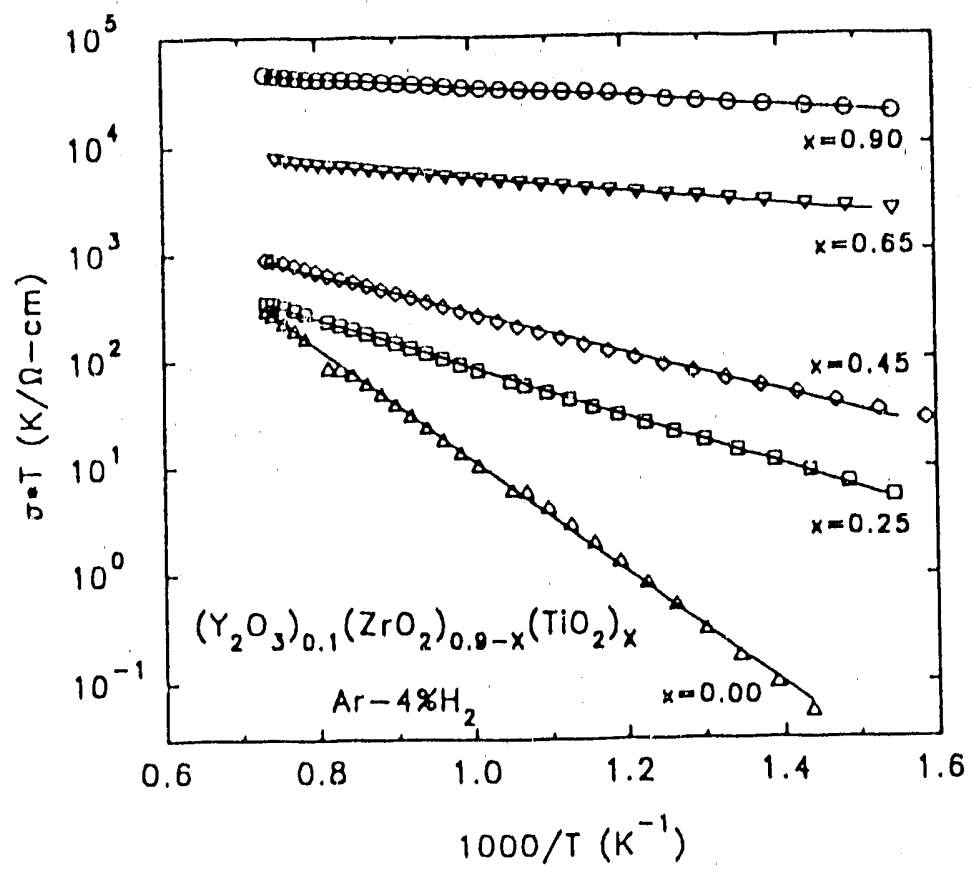

Fig. 2. Electrical conductivity of $(0.1) \mathrm{Y}_{2} \mathrm{O}_{3}-(0.9-\mathrm{x}) \mathrm{ZrO}_{2}-(\mathrm{x}) \mathrm{TiO}_{2}$ in $4 \% \mathrm{H}_{2}-96 \%$ Argon.

continuing fluorite structure at all compositions. The higher ionic conduction for $\mathrm{x}=0.9$ results because $\mathrm{Y}_{2} \mathrm{O}_{3}$ stabilized $\mathrm{CeO}_{2}$ has a higher ionic conductivity than $\mathrm{Y}_{2} \mathrm{O}_{3}$ stabilized $\mathrm{ZrO}_{2}$.

In $\mathrm{Ar}-4 \% \mathrm{H}_{2}$, the electrical conductivities of $(0.1) \mathrm{Y}_{2} \mathrm{O}_{3}-(0.9-\mathrm{x}) \mathrm{ZrO}_{2}-(\mathrm{x}) \mathrm{TiO}_{2}$ are higher than equivalent compositions of $(0.1) \mathrm{Y}_{2} \mathrm{O}_{3^{-}}(0.9-\mathrm{x}) \mathrm{ZrO}_{2}-(\mathrm{x}) \mathrm{CeO}_{2}$. (The activation energies and $\log \left(\sigma_{0}\right)$ values for the $\mathrm{CeO}_{2}$ system are summarized in Table 2.) At $1273 \mathrm{~K}$ in As-4\% $\mathrm{H}_{2}$, the electrical conductivities of $(0.1) \mathrm{Y}_{2} \mathrm{O}_{3}-(0.9-\mathrm{x}) \mathrm{ZrO}_{2^{-}}(\mathrm{x}) \mathrm{TiO}_{2}$ with $\mathrm{x}=0.65$ and $\mathrm{x}=0.90$ are 5.4 and $33.0^{\circ}(\Omega-\mathrm{cm})^{-1}$, respectively, which are larger than the corresponding values of 1 and $3(\Omega-\mathrm{cm})^{-1}$ in the $(0.1) \mathrm{Y}_{2} \mathrm{O}_{3^{-}}(0.9-\mathrm{x}) \mathrm{ZrO}_{2^{-}}(\mathrm{x}) \mathrm{CeO}_{2}$ system with $\mathrm{x}=0.65$ and $\mathrm{x}=0.90$, respectively.

The changes in electrical conductivity with additions of $\mathrm{TiO}_{2}$ occur more uniformly than changes for $\mathrm{CeO}_{2}$ additions reported previously. ${ }^{2,3}$ The activation energies in Table 1 for the (0.1) $\mathrm{Y}_{2} \mathrm{O}_{3}-(0.9-\mathrm{x}) \mathrm{ZrO}_{2}-(\mathrm{x}) \mathrm{TiO}_{2}$ system in air are generally higher than the corresponding activation energies in Table 2 for the $(0.1) \mathrm{Y}_{2} \mathrm{O}_{3} \cdot(0.9-\mathrm{x}) \mathrm{ZrO}_{2}-(\mathrm{x}) \mathrm{CeO}_{2}$ system; however, the activation energies in $\mathrm{Ar}-4 \% \mathrm{H}_{2}$ are much lower for the $(0.1) \mathrm{Y}_{2} \mathrm{O}_{3}-(0.9-\mathrm{x}) \mathrm{ZrO}_{2}-(\mathrm{x}) \mathrm{TiO}_{2}$ system. The changes in $\log \left(\mathrm{c}_{0}\right)$ values are similar for the two systems in $\mathrm{Ar}-4 \% \mathrm{H}_{2}$. Since $\mathrm{CeO}_{2}$ can stabilize $\mathrm{ZrO}_{2}$ similarly to $\mathrm{Y}_{2} \mathrm{O}_{3}$, the $(0.1) \mathrm{Y}_{2} \mathrm{O}_{3}-(0.9-\mathrm{x}) \mathrm{ZrO}_{2}-(\mathrm{x}) \mathrm{CeO}_{2}$ system is also considered to be predominately ionic conducting in air, but becomes a mixed conducting system in Ar-4\% $\mathrm{H}_{2}$.

For application to solid oxide fuel cells, the goal of this effort is to achieve fuel electrode conductivities, under reducing conditions, that are near to the conductivity of the state-of-the-art air electrode material, $\mathrm{La}_{0.9} \mathrm{Sr}_{0.1} \mathrm{MnO}_{3}$. The conductivity of this manganite at $1273 \mathrm{~K}$ is $135(\Omega-\mathrm{cm})^{-1}$. 


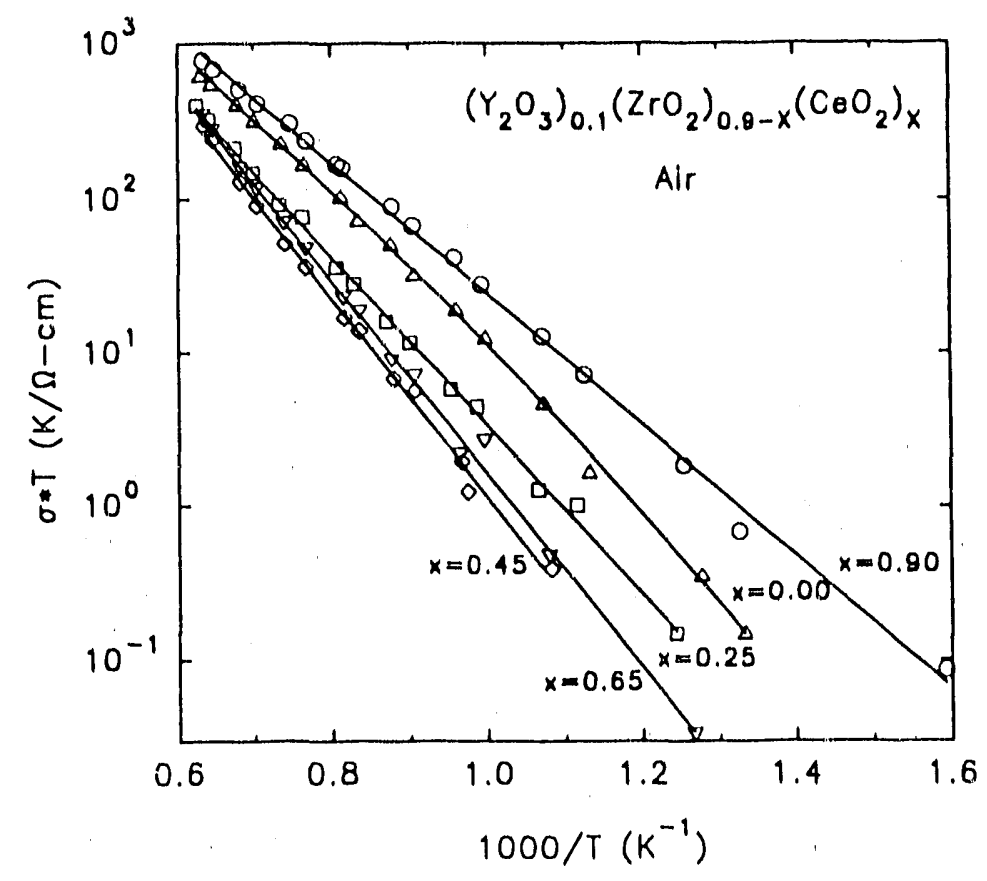

Fig. 3. Electrical conductivity of $(0.9-x) \mathrm{ZrO}_{2} \cdot(x) \mathrm{CeO}_{2} \cdot(0.1) \mathrm{Y}_{2} \mathrm{O}_{3}$ in Air.

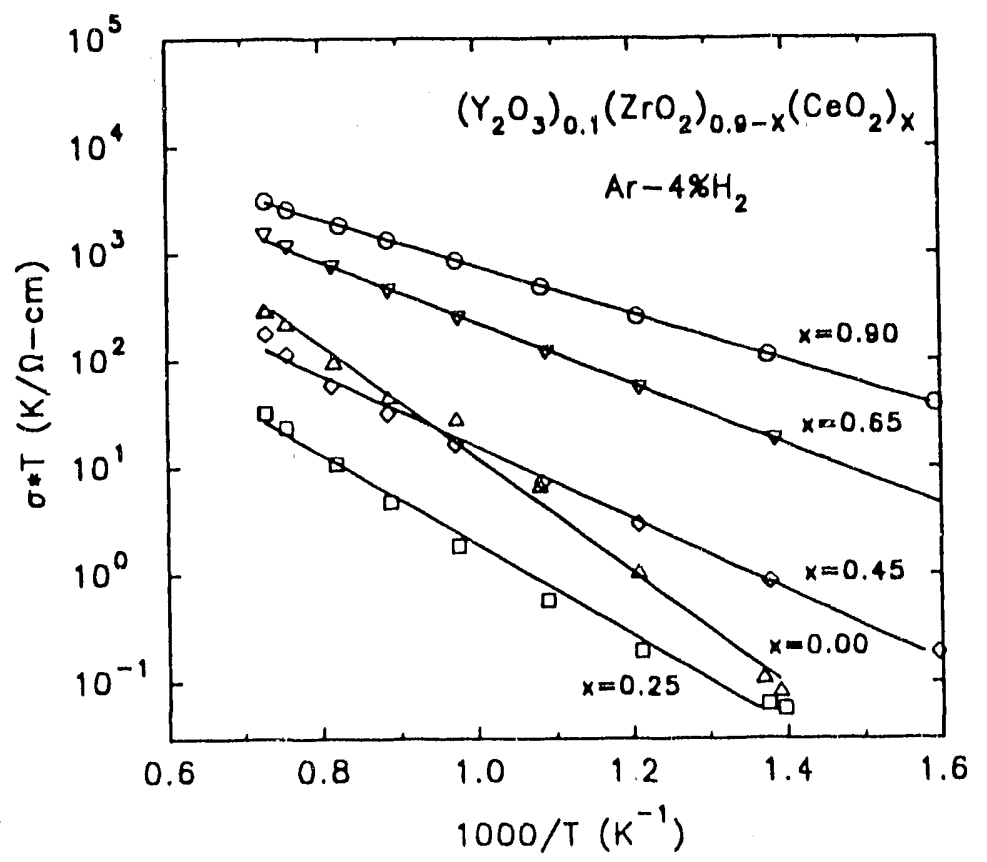

Fig. 4. Electrical conductivity of $(0.9-\mathrm{x}) \mathrm{ZrO}_{2} \cdot(\mathrm{x}) \mathrm{CeO} 2^{\cdot} \cdot(0.1) \mathrm{Y}_{2} \mathrm{O}_{3}$ in $4 \% \mathrm{H}_{2}-96 \%$ Argon. 
Based on these results to date, it appears that systems containing $\mathrm{TiO}_{2}$ and $\mathrm{ZrO}_{2}$ have a greater potential than systems with $\mathrm{CeO}_{2}$ and $\mathrm{ZrO}_{2}$ for developing high electronic conducting oxides as SOFC fuel electrodes. It is anticipated that efforts to replace $\mathrm{Y}_{2} \mathrm{O}_{3}$ with a rare-earth oxide with variable valency, such as $\operatorname{Pr}_{6} \mathrm{O}_{11}$, can result in even higher electronic conductivities in reducing atmosphere with lower additive concentrations.

\section{Electrochemical Processes}

The performance of high-temperature solid electrolyte systems, such as SOFCs, is often dependent upon the electrochemical processes that occur at solid-solid-gas interfaces. All high-temperature solid electrolyte processes involve one or more solid-solid-gas interfaces, particularly those between the electrode, electrolyte and gases. Changes can occur at these interfaces or in the materials associated with these interfaces that can alter reaction mechanisms and rates of reactions. It is important to understand these electrochemical processes and the influences that material properties and interfaces, electrical current and potential, temperature, environment and time exert on these processes.

Tab'e 2. Activation Fnergy of $(0.9-\mathrm{x}) \mathrm{ZrO} 2 \times \mathrm{xCeO} 2 \cdot 0.1 \mathrm{Y} 2 \mathrm{O} 3$ in Air and $4 \%$ Hydrogen - $96 \%$ Argon

\begin{tabular}{|c|c|c|}
\hline Mole $\% \mathrm{CeO}_{2}$ & \multicolumn{2}{|c|}{ Activation Energy, $\mathrm{eV}^{*}$} \\
\hline$x$ & Air & $4 \% \mathrm{H}_{2}$ \\
\hline 0.00 & 1.070 & 1.051 \\
\hline 0.25 & 0.671 & 1.086 \\
\hline 0.45 & 0.473 & 1.333 \\
\hline 0.65 & 0.521 & 1278 \\
\hline 0.90 & 0.404 & 0.758 \\
\hline
\end{tabular}

*Determined from best fit of slope from $\log \sigma \mathrm{K}$ versus $1 / \mathrm{K}$. 
The performance of the air electrode-electrolyte interface in a SOFC is mainly governed by the cathodic processes. Currently, strontium-doped lanthanum manganite (LSM) is the material of choicc for a SOFC air electrode bcrause it has fairly high temperature stability in atmospheres in the $10^{-1}$ to $10^{5} \mathrm{~Pa} \mathrm{p}\left(\mathrm{O}_{2}\right)$ range, it has high electrical conductivity $\left(135 \mathrm{\Omega}^{-1} \mathrm{~cm}^{-1}\right.$ at $\left.1273 \mathrm{~K}\right)$ and its coefficiont of thermal expansion is close to that of the electrolyte. Its high electrical conductivity is due to the strontium doping. When a fraction of the $\mathrm{La}^{3+}$ is replaced by divalent $\mathrm{Sr}^{2+}$, the charge deficit is compensated by a valence change on manganese ions from $\mathrm{Mn}^{3+}$ to $\mathrm{Mn}^{4+}$. This change can lead to an increase in the electronic (hole $h$ ) conductivity. The oxygen ion conduction also may be enhanced with doping due to the formation of oxygen vacancies $\left(V_{0}{ }^{\prime \prime}\right)$. This has the effect of increasing the number of potential reaction sites in the air electrode at the electrolyte interface. 6,7

Normally the reaction zone occurs at the physical triple phase boundary (tpb) between an electrically conducting, porous air electrode, the oxygen gas and the oxygen ion conducting electrolytc. However, mixed electronic/ionic conduction in the air electrode can enlarge the reaction zone by increasing the number of sites where oxygen can be adsorbed and charge transfer can take place. The oxygen ions can move through the air electrode into the electrolyte without having to be formed directly at the tpb. In addition, the combination of $\mathrm{Mn}^{4+}$ and $\mathrm{Mn}^{3+}$ sites in LSM can stimulate electrocatalytic activity of the oxygen adsorption and charge transfer process. 8,9

\section{Air Electrode/Electrolyte Reactions}

The cathodic reactions at the interface between the air electrode and electrolyte can be represented by two processes:

$$
\begin{aligned}
& 1 / 2 \mathrm{O}_{2} \text { (gas) }+\mathrm{V}_{\mathrm{o}} \cdot(\mathrm{LSM})_{\text {surf }} \cdots \cdots \mathrm{O}_{\mathrm{o}}{ }^{\mathrm{x}}(\mathrm{LSM})_{\text {surf }}+2 \mathrm{~h} \cdot(\mathrm{LSM}) \\
& \mathrm{O}_{\mathrm{o}}{ }^{\mathrm{x}}(\mathrm{LSM})_{\text {bulk }}+\mathrm{V}_{\mathrm{o}} \text { "(electrolyte) } \cdots \cdots \mathrm{O}_{\mathrm{o}}{ }^{\mathrm{x}}(\text { electrolyte })+\mathrm{V}_{\mathrm{o}}{ }^{\prime \prime}(\mathrm{LSM})_{\text {bulk }}
\end{aligned}
$$

Reaction (2) occurs at the porous LSM electrode-permeating gas (oxygen) interface next to a $\mathrm{Mn}$ reaction site, a site where the oxygen adsorption is enhanced. The oxygen gas molecule dissociates, and each atom transfers two charges to become an oxygen ion on the LSM surface. Bulk oxygen ionic conduction within the LSM material then provides oxygen ions that can pass directly into the solid electrolyte anywhere along the LSM-solid electrolyte interface as described by Reaction (3). Thus, Reaction (3) is not confined to take place at the tpb as is typical with a conventional electrolyteporous metal air electrode, but has extended the effective reaction zone over the surface of the LSM material. The size of the reaction zone should depend upon the diffusion rate of the oxygen vacancies in the LSM material. 
The net cathodic reaction obtained by adding Reactions (2) and (3) is:

$1 / 2 \mathrm{O}_{2}$ (gas) $+\mathrm{V}_{\mathrm{o}}$ " (electrolyte) $\ldots . . .>2 \mathrm{~h} \cdot(\mathrm{LSM})+\mathrm{O}_{0}{ }^{\mathrm{x}}$ (electrolyte)

Reaction (4) would describe the cathodic reaction that normally takes place at a solid electrolyteporous $\mathrm{Pt}$-oxygen gas tpb if the $2 \mathrm{~h}$ ( $(\mathrm{LSM})$ on the right-hand side were replaced by $2 \mathrm{e}^{*}(\mathrm{Pt})$ on the left-hand side of Equation (4). Thus, the net cathodic reaction rate would be limited by the number of available reaction sites or essentially the length of the (one dimensional) tpb. Therefore, efficient long-term operation of a dense electrolyte-porous metal or ceramic electrode depends upon maintenance of a chemically and physically stable interface between the porous electrode and dense electrolyte. However, for the case of an LSM electrode, the requirement of a stable tpb is relaxed somewhat since charge transfer can occur on the (three-dimensional) LSM-gas surface near the tpb. Then oxygen ionic conduction in the LSM provides the pathway for ionic conduction into the electrolyte via Reaction (3).

Enhanced electrocatalytic activity, which apparently occurs at reaction sites adjacent to the $\mathrm{Mn}$ reaction sites on the LSM surface, is related to enhanced electronic conductivity in the bulk LSM. It also appears that cathodic reaction rates are enhanced by increased oxygen ionic conductivity in LSM. However, it is not clear what the transport LSM properties and composition, the operating conditions, or the electrode-electrolyte interface structure should be to obtain optimum electrocatalytic activity and cathodic reaction rates while preserving physical and chemical stability during long-term SOFC operation.

This section describes an experimental method to elucidate the separate cathodic reactions (2) and (3) in nore detail.

\section{Unbonded Interface Cell}

An electrochemical cell using unbonded solid interfaces was developed to investigate the hightemperature reactions at materials interfaces without the influences of interface morphology variations resulting from cell fabrication. The unbonded interface cell (UIC) design utilizes separately fabricated dense or porous electrode and electrolyte samples. A solid electrolyte disc is pressed against a smaller solid electrode disc. The interface consists of two ground surfaces in contact with a slight pressure applied. Platinum is bonded to the outer surfaces of the electrode and electrolyte and is connected to an external electric circuit for measurements. Although only a small fraction of the surfaces are in contact, the contact area can be calculated from the data.

This experimental design resolves the difficult problems of preparing reproducible interfaces by co-sintering of the electrode and clectrolyte. In addition, the relative ease of ccll fabrication and 
assembly and the repeated and multiple use of the same samples make it possible rapid, reproducible measurements of the electrochemical processes at the materials interfaces. Similar cells can be made of other electrode and interconnection materials.

The current experiments utilized a $\mathrm{La}_{0.9} \mathrm{Sr}_{0.1} \mathrm{MnO}_{3}$ electrode composition together with a stabilized ( 8.0 mole percent yttria) zirconia electrolyie. For comparison, the method of analysis and the $U^{r}$; design also were tested with platinum metal electrodes of two different configurations against the same zirconia electrolyte sample tested with the LSM electrodes. To study materials properiies, materials interaction, and cell and interface performance, ac impedance spectroscopy (IS) over a wide range of frequericies was used. Also, small-amplitude complex impedance spectra were obtained while a dc polarization bias (either cathodic or anodic) was applied to the UIC. The combination of these measurements allows an examination of a number of electrnchemical and electrical processes. In addition to direct examination of polarization and charge transfer, the measurements can be used to evaluate the role of electrode/electrolyte interface, adsorption reactions, defect generation and recombination, diffusion, degradation, and grain and grain boundary conductivity on these reactions.

\section{${\underline{0.08 Y_{2}}}_{2} \underline{O}_{3}-0.92 \mathrm{ZrO}_{2}$ Eleccrolyte}

Impedance spectroscopy measurements were used to determine the electrical conductivity of sintered $0.08 \mathrm{Y}_{2} \mathrm{O}_{3}-0.92 \mathrm{ZrO}_{2}(\mathrm{ZSY})$. The data include results obtained for the three additional sintered Z8Y samples used in the UIC experiments. The electrical conductivity for all the data, corrected for different sample thicknesses, can be represented analytically by the two expressions:

$$
\begin{aligned}
& \sigma=0.786 \times 10^{6} \mathrm{~K}^{-1} \mathrm{e}^{-0.91 / \mathrm{kT}}(\Omega \mathrm{cm})^{-1} \text { for } \mathrm{T}>770 \mathrm{~K} \\
& \sigma=23.38 \times 10^{6} \mathrm{~K}^{-1} \mathrm{e}^{-1.13 / \mathrm{kT}}(\Omega \mathrm{cm})^{-1} \text { for } \mathrm{T}<770 \mathrm{~K}
\end{aligned}
$$

In these expressions, 0.91 and $1.13 \mathrm{eV}$ are the activation energies for ionic conduction in the Z8Y material in two temperature regions above and below $770 \mathrm{~K}$. These results agree with the results reported earlier for similar material. ${ }^{1}$

\section{Electrode-Electrolyte Interface}

The electrochemical reactions occurring at the electrode-electrolyte interface without the influence of interface morphology were examined using the UIC. Details of the UIC design were presented earlier. $^{1,2}$

The same Z8Y samples examined abnve were prepared for use in the UIC by removing the $\mathrm{Pt}$ paste from one face and roughening the surface with 400 grit SiC paper. Three different electrode 
configurations were tested. They were a dense air-sintered $\mathrm{La}_{0.9} \mathrm{Sr}_{0.1} \mathrm{MnO}_{3}$ disc ${ }^{\mathrm{b}}$ (6.35 mm diameter) with a roughened surface, a machined $\mathrm{Pt}$ disc (6.35 min diameter) with a smooth surface and a solidified $\mathrm{P}$, bead $(\sim 1.1 \mathrm{~mm}$ diameter). For the UIC configuration with the first two electrodes, the interface consisted of multiple "point" contacts around which gases could flow. The $\mathrm{Pt}$ bead electrode formed a "single-point contact" with the Z8Y electrolyte.

For the electrical measurements, the reference and counter electrodes were connected in common to the electrolyte and the working electrode was connected to the air electrode side of the UIC. Because of the small contact area between the electrode and electrolyte, the interface impedance (typically 100 to 10,000 ohms) dominates the other cell impedances (typically 1 to 20 ohms) such as those due to the $\mathrm{Pt}$ wire leads, the outer $\mathrm{Pt}$ electrodes and the electrolyte and electrode bulk impredances.

For this evaluation of the electrolyte-air electrode interface, temperatures and oxygen partial pressures representative of the SOFC were of interest. A typical set of complex impedance dispersion curves (Nyquist plots) for isobaric and for isothermai conditions are shown in Figures 5a and 5b, respectively. The Figure 5a curves were obtained at different temperatures (873 to $1173 \mathrm{~K}$ ) for the $\mathrm{Z} 8 \mathrm{i} / \mathrm{Pt}$ bead cell in air. The Figure $5 \mathrm{~b}$ curves were ubtained at different partial pressures of oxygen $\left(0.2\right.$ to $0.2 \times 10^{5} \mathrm{~Pa}$ ) for the $78 \mathrm{Y} / \mathrm{LSM}$ cell at $1173 \mathrm{~K}$. In these experiments the partial pressure of oxygen $\left(\mathrm{p}\left(\mathrm{O}_{2}\right)\right)$ was adjusted by mixing argon and oxygen gases. Also shown on the curves are the upper and lower frequency limits ( $10^{5}$ and $1 \mathrm{~Hz}$, respectively) covered in the IS sweeps.

Generally, complex impedance spectra are analyzed in terms of equivalent circuits with resistive-, capacitive- and inductive-like elements in series or parallel combinations. When diffusion-controlled electrode processes occur, other elements such as the Warburg impedance are required. ${ }^{10}$ Because of length, the circuit expressions are not described in detail here. However, at high frequencies where diffusion limits the cell processes, the complex impedance makes a straight line with a $45^{\circ}$ angle to the axes. The high frequency intercept represents the bulk resistance $\left(R_{B}\right)$ of the electrolyte. At lower frequencies, the reaction kinetics become the rate determining process and the curve resembles a semi-circle, which is represented by a parallel resistor-capacitor circuit. The resistance is called the polarization resistance $\left(R_{p}\right)$ and is obtained from the difference between the low frequency intercept $\left(R_{2}\right)$ and $R_{B}$. (See Figure 5a where $R_{B}$ and $R_{2}$ are marked for the $1073 \mathrm{~K}$ curve.) The polarization resistance, $R_{p}$, is inversely proportional to the interface reaction rate and will depend on the reactant and product activities in Equation (2) as well as on temperature and $\mathrm{p}\left(\mathrm{O}_{2}\right)$. For a wide range of temperature and $p\left(\mathrm{O}_{2}\right)$ values, the IS curves for the three different UIC configurations resembled the characteristic shapes shown in Figures $5 \mathrm{a}$ and $5 \mathrm{~b}$ where, apparently, diffusion must limit the process at

\footnotetext{
${ }^{b}$ Westinghouse Powder \#178 isostatically pressed and air-sintered $(1773 \mathrm{~K}, 1 \mathrm{~h})$ to a finál density of $6.17 \mathrm{~g} / \mathrm{cm}^{3}$ with an electrical conductivity of $50(\Omega \mathrm{cm})^{-1}$ at $173 \mathrm{~K}$
} 


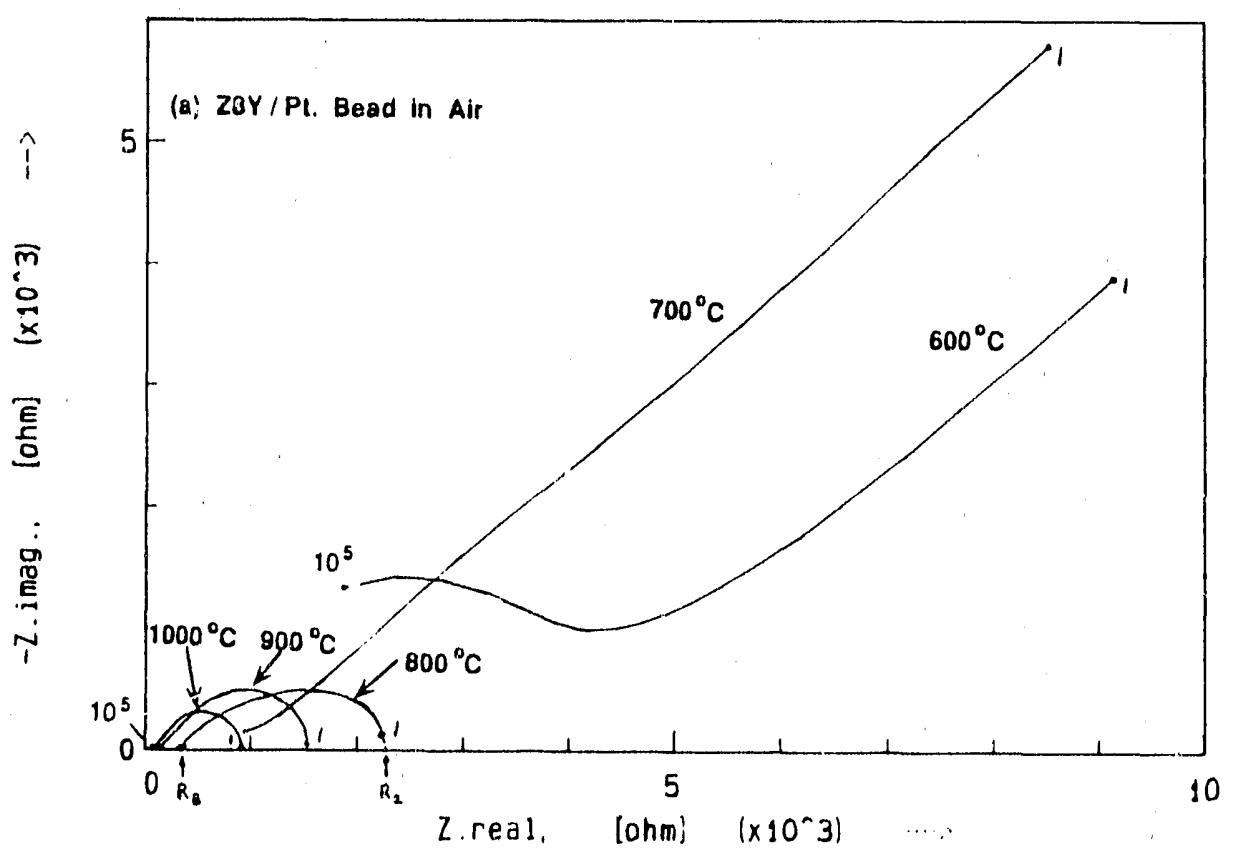

(a)

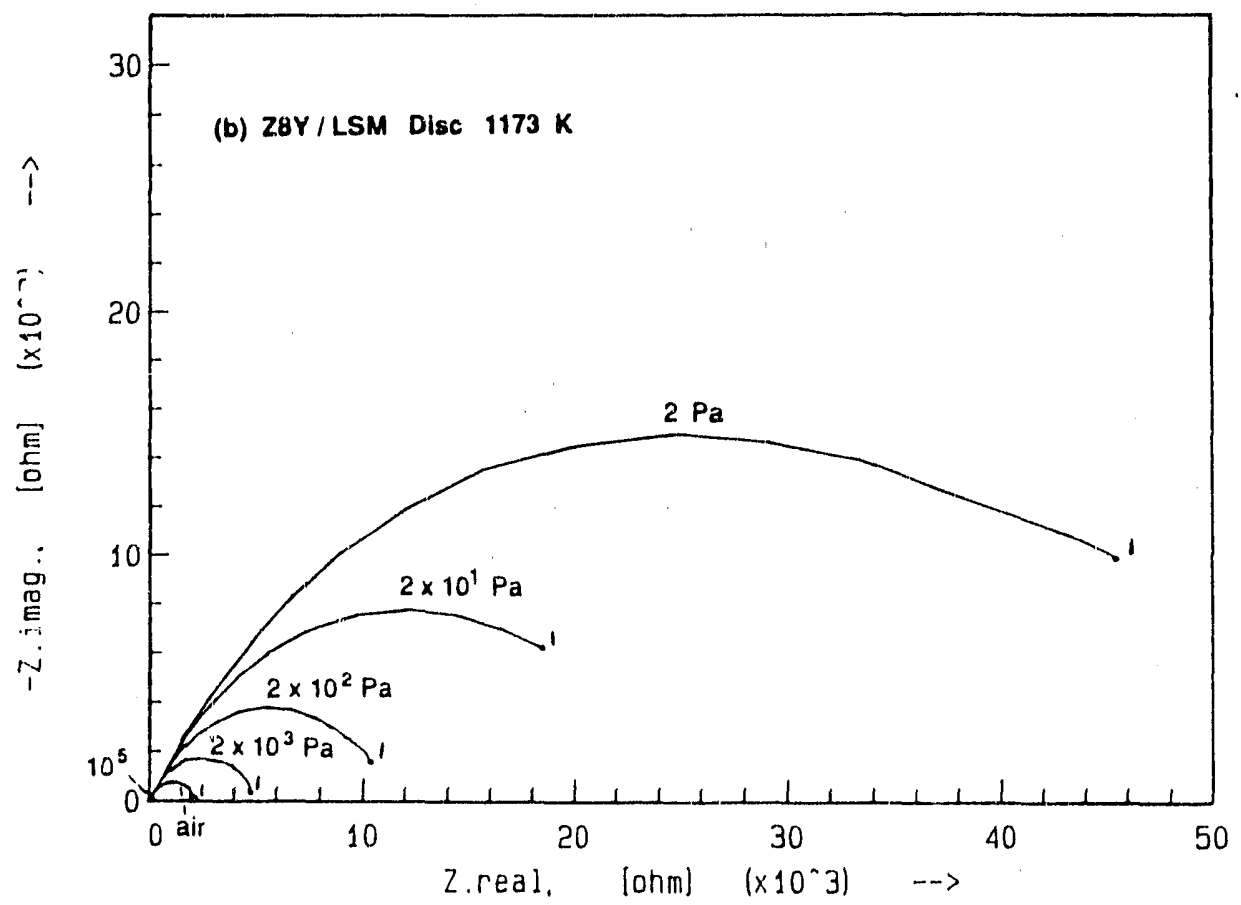

(b)

Fig. 5. Complex impedance of the Z8Y/Pt bead and Z8Y/LSM disc UIC cell configurations, respectively. Figure 9a shows typical temperature variation for fixed $p\left(\mathrm{O}_{2}\right)$ while Figure 9's shows typical $p\left(O_{2}\right)$ variation for fixed temperature. $R_{2}$ and $R_{B}$ intercepts are indicated on the $800^{\circ} \mathrm{C}$ curve only. 
high frequencies (straight line at about $45^{\circ}$ to axes) and reaction kinetics must limit the process at low frequencies (semi-circular arc). Since the variations of $R_{B}$ anc $R_{p}$ as a function of temperature and $\mathrm{p}\left(\mathrm{O}_{2}\right)$ can be described in terms of physical processes taking place at the electrolyte-electrode interface, the tollowing analysis emphasizes these two parameters.

Figure 6 shows the temperature dependence of $R_{B}$ for the three cell configurations plotted in Arrhenius form. The $T / R_{B}$ data approximately fit straight lines with similar slopes all of which were only slightly larger than $0.91 \mathrm{eV}$, the activation energy of the Z8Y electrolyte. Also, $R_{B}$ was fnund to be independent of $\mathrm{p}\left(\mathrm{O}_{2}\right)$. The data shown in Figure 6 could be normalized using Newman's formula ${ }^{11}$

$$
R=\frac{1}{4 \sigma r} \quad(\Omega)
$$

which relates the electrolyte resistance to the contact size. In this formula, a conductor makes a point contact of effective radius $r$ with a semi-infinite electrolyte of conductivity $\sigma$. Because of the nonuniform current flow lines in the electrolyte, the net electrolyte resistance is $\mathrm{R}$. Although derived for

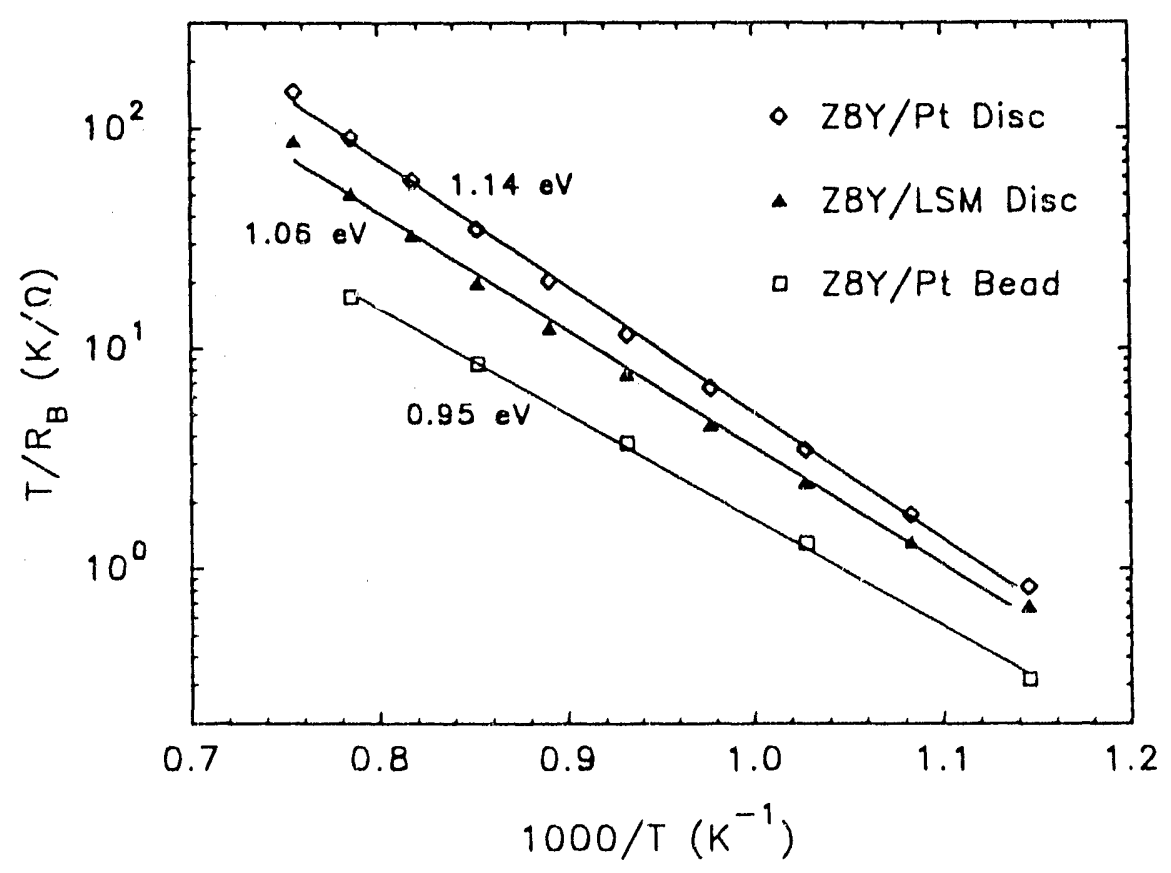

Fig. 6. Temperature dependence of $R_{B}$ for three UIC configurations. The same Z8Y electrolyte was used in each configl" ation while the air electrode was either the Pt disc, $\mathrm{Pt}$ bead, or the LSM disc. 
a single-point contact, Newman's formula should be applicable to multiple point contacts as long as the contacts are well separated. Thus, $R$ in Newnian's formula corresponds to our measured $R_{B}$ values and $\sigma$ is the conductivity of Z8Y given by Equations (5) and (6). If the effective contact radius $r$ is temperature independent, then $R_{B}$ should have the same activation enargy as the electrolytc ionic conductivity.

Later, $r$ was calculated from measured $R_{B}$ and $\sigma$ values for each cell configuration and $2 \pi r$ was used as an estimate of the contact psrimeter, a three-phase boundary along which the electrochemical reactions are assumed to occur. Figures $7 a$ and $7 b$ are isobaric plots of $R_{p}{ }^{-1}$ versus $1000 / T$ for the LSM and Pt disc "multiple-point contact" cells, respectively. For each electrode the activation energies, calculated for each $\mathrm{p}\left(\mathrm{O}_{2}\right)$, appear to divide into two sub-groups. For $\mathrm{p}\left(\mathrm{O}_{2}\right)$ values in the range $10^{5}$ down to $2 \times 10^{3} \mathrm{~Pa}$ (0.93 to $0.02 \mathrm{~atm}$., respectively) the activation energies are higher. Also, the $\mathrm{p}\left(\mathrm{O}_{2}\right)$ sub-group activation energies for the LSM electrode (2.1 and $1.7 \mathrm{eV}$ ) are higher than those for the $\mathrm{Pt}$ disc electrode $\mathrm{p}\left(\mathrm{O}_{2}\right)$ sub-group values $(1.3$ and $\sim 0.8 \mathrm{eV})$. The $\mathrm{R}_{\mathrm{p}}{ }^{-1}$ versus $1000 / \mathrm{T}$ for the $\mathrm{Pt}$ bead "single-point contact" cell was obtained in air only. It had an activation energy of $1.3 \mathrm{eV}$, which matched that of the $\mathrm{Pt}$ disc electrode.

Figures $8 \mathrm{a}$ and $8 \mathrm{~b}$ are isotherm plots of $\log \mathrm{R}_{\mathrm{p}}{ }^{-1}$ versus $\log \mathrm{p}\left(\mathrm{O}_{2}\right)$ for the LSM and $\mathrm{Pt}$ disc electrodes, respectively. Many times the reaction rate is limited by a si.ngle process in such a way that $\mathrm{R}_{\mathrm{p}}^{-1}$ is proportional to $\left(\mathrm{p}\left(\mathrm{O}_{2}\right)\right)^{\mathrm{n}}$. The power $\mathrm{n}$ can indicate the nature of the rate limiting process under certain conditions. ${ }^{8,12-14}$ In Figures $8 \mathrm{a}$ and $8 \mathrm{~b}$, the index $\mathrm{n}$ is noted for each temperature. It is observed that $\mathrm{n}$ is near 0.25 at $1073 \mathrm{~K}$ for both cells and increases slightly for higher temperatures; $\mathrm{n}$ for the $\mathrm{Pt}$ disc is somewhat higher than $\mathrm{n}$ for the LSM disc at $1273 \mathrm{~K}$ (0.44 and 0.35 , respectively). The $\mathrm{n}$ value for the $\mathrm{Pt}$ bead electrode at $1173 \mathrm{~K}$ (not shown) was 0.51 .

After the ac impedance analysis had been completed, dc polarization curves for the LSM and $\mathrm{Pt}$ bead cell configurations were determined at $1173 \mathrm{~K}$ with an air atmosphere. These results are shown together in Figure 9. The overvoltage values were corrected for IR drop by using $R_{B}$ values deter mined in the ac impedance experiments for each cell. Specific currents were calculated by dividing the measured cell current by the calculated "effective reaction length" $2 \pi \mathrm{r}$ using Equation (7) to find $r$. The $I(V)$ curves shown in Figure 9 agree in magnitude and shape with the polarization characteristics for $\mathrm{La}_{0.9} \mathrm{Sr}_{0.1} \mathrm{MnO}_{3}$ and $\mathrm{Pt}$ electrodes reported by Hammouche et al. ${ }^{15}$ for a similar cell design and conditions.

Figure 10 shows the temperature dependence of the effective reaction length, which is calculated by the Newman formula from the measured values of $R_{B}$ and assuming that $\sigma$ is strictly the $Z 8 Y$ electrolyte conductivity given by Equations (5) and (6). Here it is observed that the effective reaction lengths of the LSM and $\mathrm{Pt}$ disc multiple-point contact cells increase at a greater and greater rate with increasing temperature. In contrast, the reaction length of the Pt bead single-point contact is 


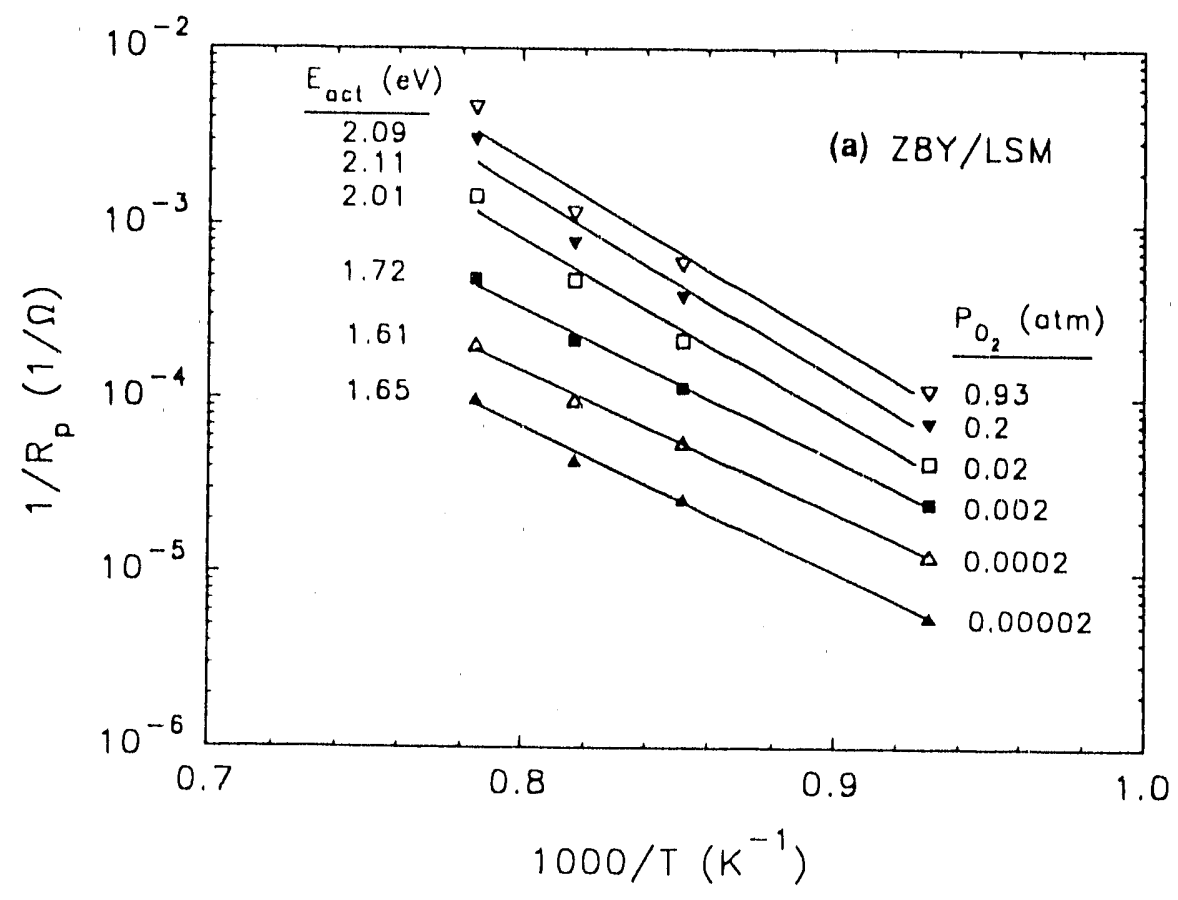

(a)

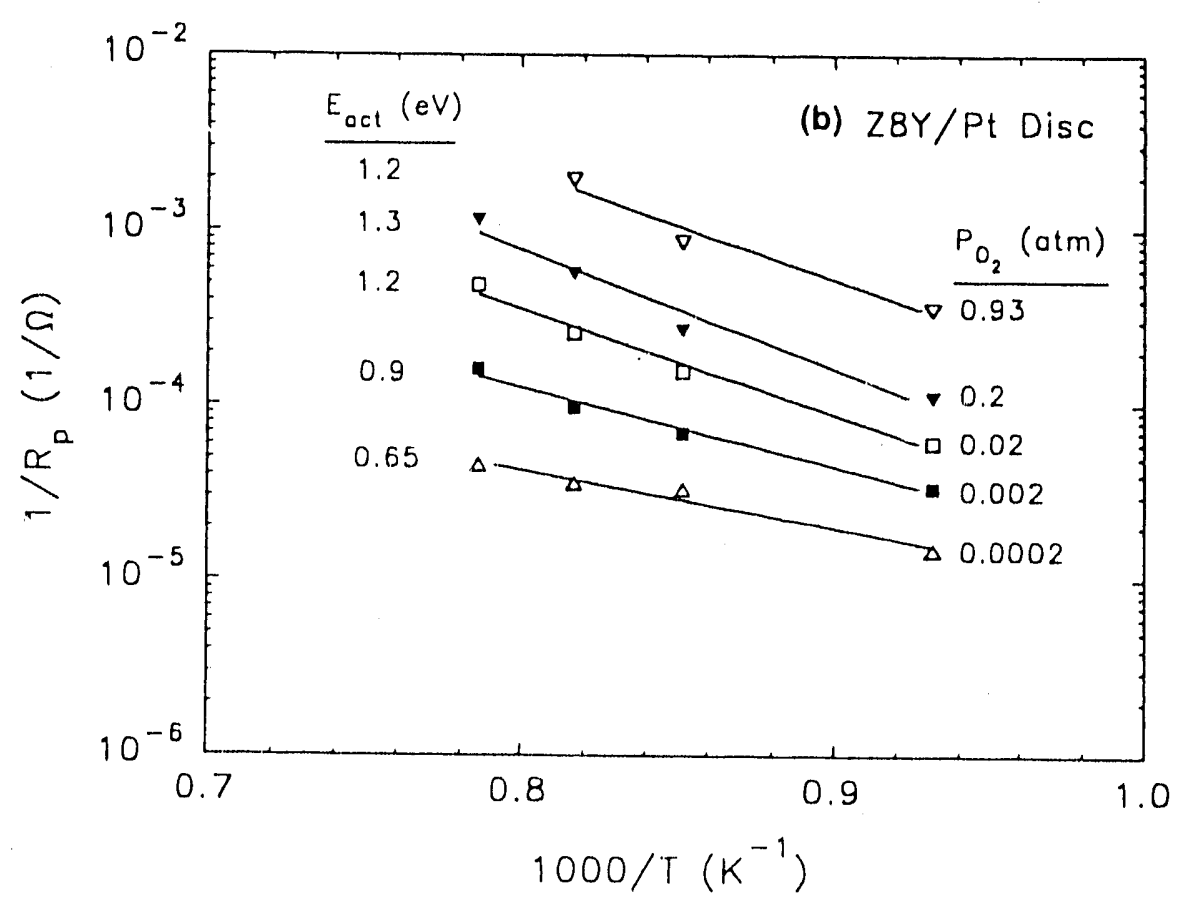

(b)

Fig. 7. Isobaric plots of temperature dependence of $R_{p}^{-1}$ for (a) the Z8Y/LSM cell and (b) the $\mathrm{Z} 8 \mathrm{Y} / \mathrm{Pt}$ disc cell. The apparent activation energies are shown for each $\mathrm{p}\left(\mathrm{O}_{2}\right)$. 


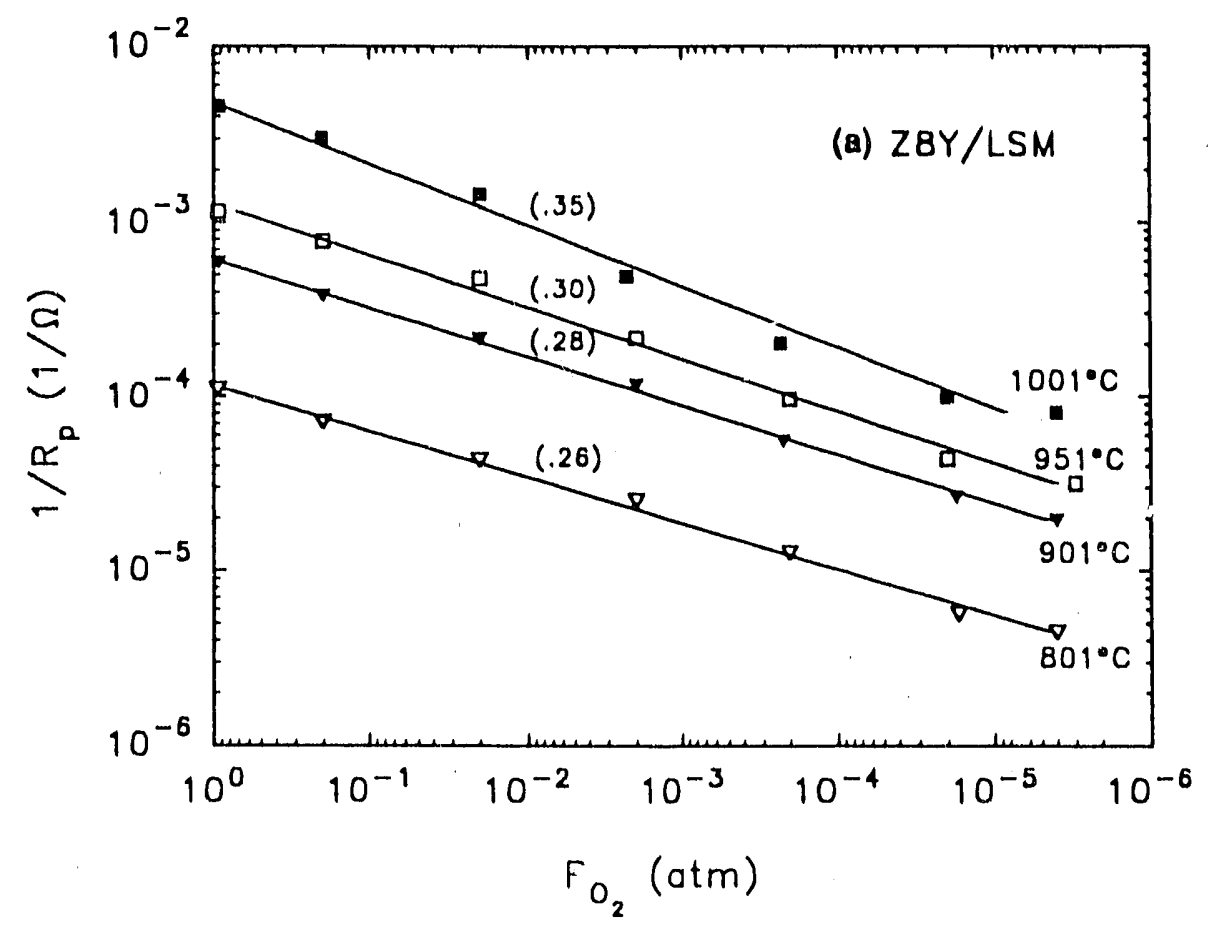

(a)

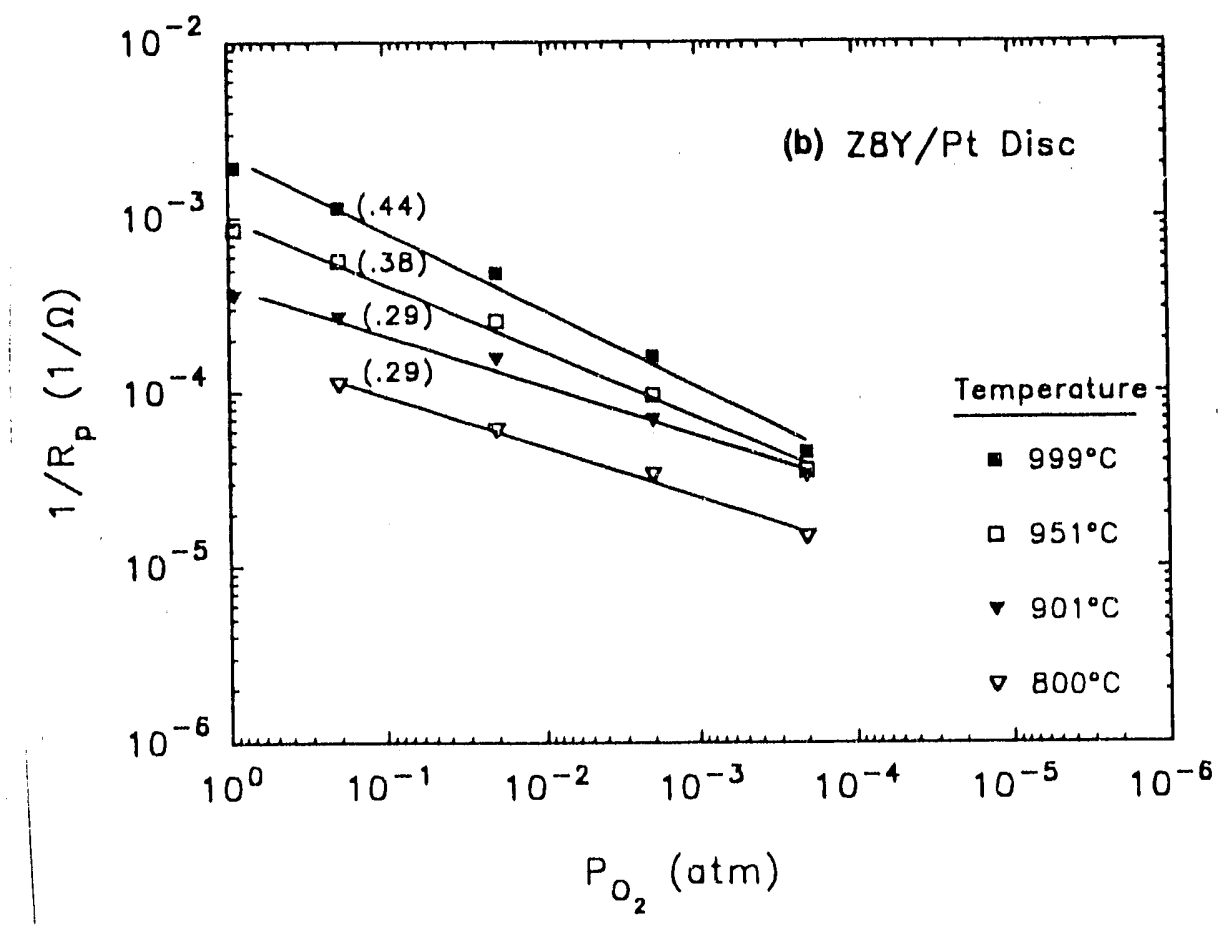

(b)

Fig. 8. Isotherm plots of oxygen partial pressure dependence of $R_{p}^{-1}$ for (a) the Z8Y/LSM cell and (b) the $\mathrm{Z} 8 \mathrm{Y} / \mathrm{Pt}$ disc cell. The index $\mathrm{n}$ from $\left(\mathrm{p}\left(\mathrm{O}_{2}\right)\right)^{\mathrm{n}}$ dependence is shown for each temperature. 
temperature independent. It was possible to discern and measure the contact perimeter length of the $P t$ bead from a SEM micrograph of the bead surface. The measured perimeter was $0.15 \pm 0.03 \mathrm{~cm}$, which corresponds very closely with the effective length of the Pt bead cell plotted in Figure 10.

\section{Combination ac Impedance and dc Bias Tests}

At $1173 \mathrm{~K}$ in air, a dc cathodic bias of $400 \mathrm{mV}$ was applied to the Z8Y/LSM ceil for a short time (a few hours). The applied bias was periodically interrupted to make an IS scan to determine $R_{B}$ and $R_{p}$ values. Preliminary results show a gradual decrease in $R_{B}$ values with time of dc bias application. Meanwhile, $R_{\ell}{ }^{-1}$ values dramatically increased. These appeared to be permanent changes. When an applied dc anodic bias of the same magnitude was applied for a period of time, the $R_{B}$ and $R_{p}$ values increised and were restored to approximately their original values.

Later, the complex impedance was measured while different $\mathrm{dc}$ anodic and cathodic bias potentials were applied to the cell. Above bias potentials of approximately $\pm 200 \mathrm{mV}, R_{p}{ }^{-1}$ values increased dramatically with increased bias potential up to $\pm 600 \mathrm{mV}$. When the dc bias was removed, the $R_{p}$ value quickly relaxed back toward its original value; however, permanent changes in both $R_{B}$ and $R_{p}$ values remained. Apparently, dc anodic or cathodic bias potentials also induce rapid modification of the interface reaction rate.

\section{Discussion}

The measurement of complex impedance of the unbonded interface between dense electrode and electrolyte samples yields information about electrochemical reactions resulting from compositional and structural interface modifications without the influence of sample morphology variations resulting from fabrication. Two IS parameters, $R_{B}$ and $R_{p}$, can be described in terms of physical processes occurring at the interface. $R_{B}$ is correlated via Newman's formula to the size of the effective reaction zone at the interface. $R_{p}{ }^{-1}$ is correlated to the reaction rate at the interface. Changes in both these parameters are sensitive measures of the the extent to which composition and operating conditions such as temperaiure, $\mathrm{p}\left(\mathrm{O}_{2}\right)$, electric potential and time influence on interface reactions.

For conditions as "ociated with SOFC air electrodes, the activation energy for the interface reaction (Equation 3) for the $\mathrm{La}_{0.9} \mathrm{Sr}_{0.1} \mathrm{MnO}_{3}$ electrode was higher than that for the $\mathrm{Pt}$ electrode ( $\sim 2 \mathrm{eV}$ compared to $1.3 \mathrm{eV}$, respectively). This suggests that the electrocatalytic activity of the $\mathrm{La}_{0.9} \mathrm{Sr}_{0.1} \mathrm{MnO}_{3}$ composition at zero or low applied potentials is lower than that of $\mathrm{Pt}$. The $\mathrm{dc}$ polarization data at $1173 \mathrm{~K}$ in air for the cathodic reaction confirm that $\mathrm{Pt}$ is catalytically better than LSM with $0.10 \mathrm{Sr}$ doping. It is expected that increased $\mathrm{Sr}$ doping will increase the electronic conductivity, and at the same time improve the electrocatalytic activity of LSM. 


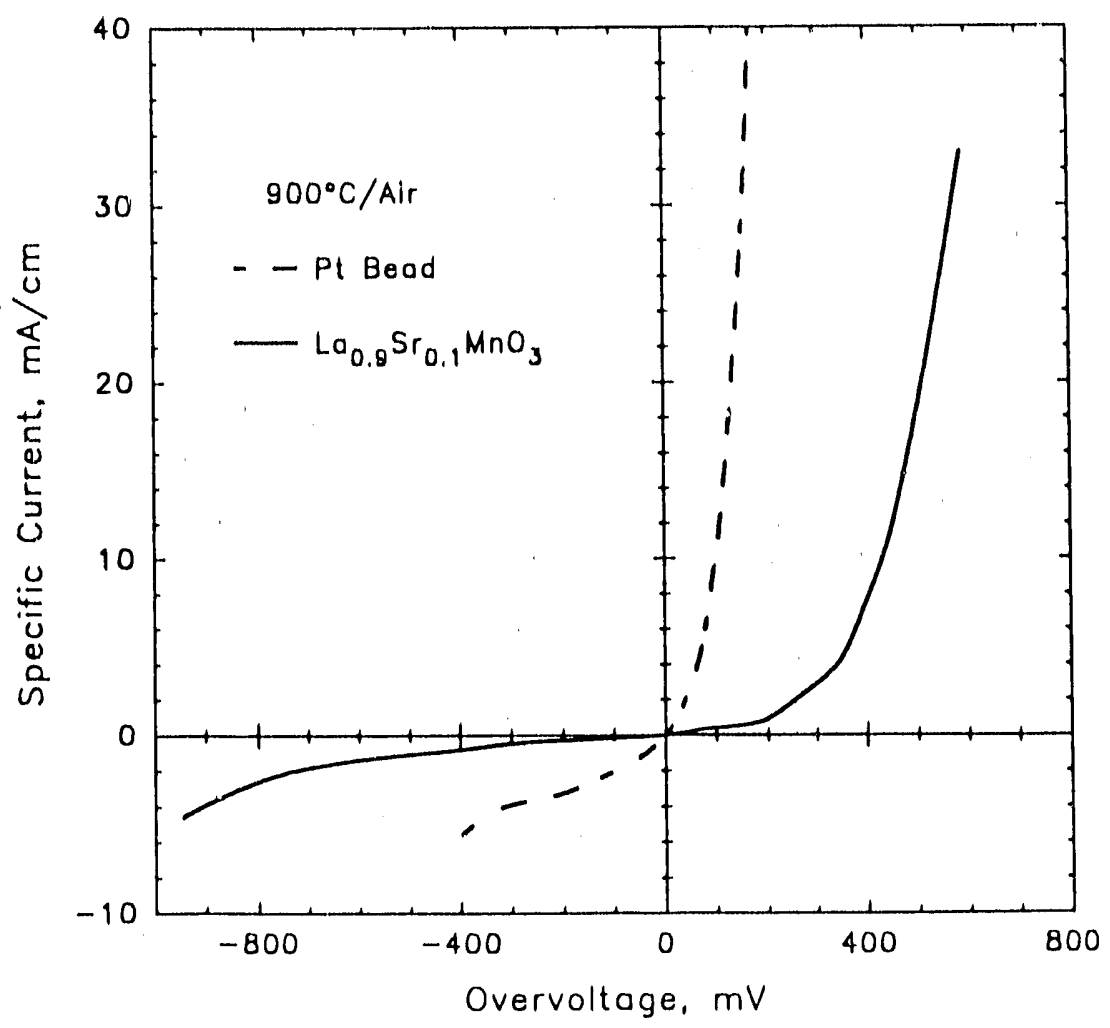

Fig. 9. DC polarization characteristics for $\mathrm{La}_{0.9} \mathrm{Sr}_{0.1} \mathrm{MnO}_{3}$ and $\mathrm{Pt}$ bead electrodes at $1173 \mathrm{~K}$ in air.

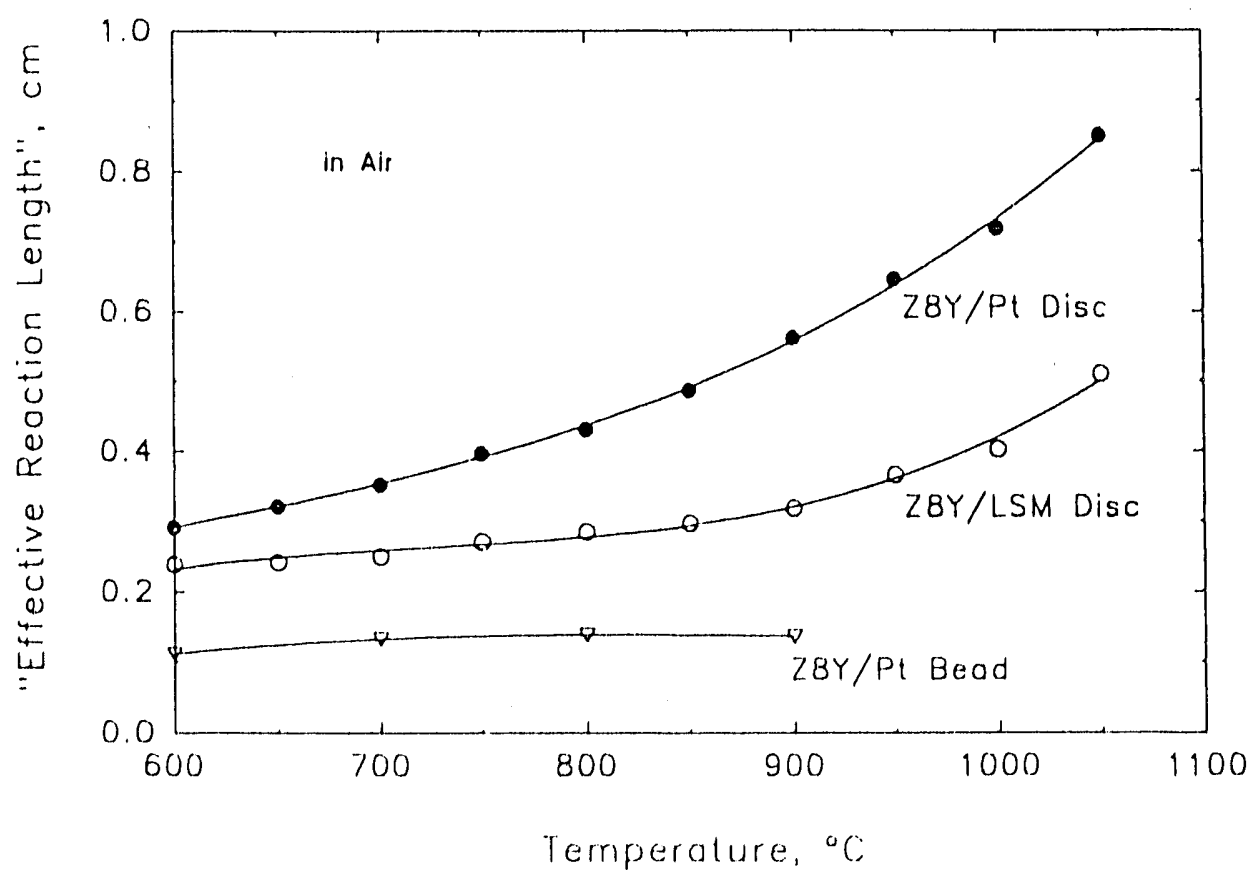

Fig. 10. Temperature dependence of the effective reaction length $(2 \pi r)$ for the Z8Y/LSM, Z8Y/Pt disc, and Z8Y/Pt bead UIC configurations. 
The experimental $n$ values for $\log _{1} / R_{p}$ versus $\log p\left(O_{2}\right)$, near $1 / 4$ for both the LSM and $\mathrm{Pt}$ disc electrodes, indicate that dissociation of the $\mathrm{O}_{2}$ molecule into adsorbed $\mathrm{O}$ atoms at the electrodeelectrolyte interface is the rate limiting reaction. In this regard, the $\mathrm{La}_{0.9} \mathrm{Sr}_{0.1} \mathrm{MnO}_{3}$ material behaves similarly to a Pt metal electrode.

Preliminary dc anodic and cathodic bias tesis indicate that the $\mathrm{La}_{0.9} \mathrm{Sr}_{0.1} \mathrm{MnO}_{3}$ electrode can be electrochemically modified to enhance the reaction rate kinetics at the electrode-electrolyte interface.

\section{Conclusions}

- An electrochemical analysis technique using ac impedance or dc polarization coupled with an unbonded interface cell (UIC) has been built and tested utilizing a $\mathrm{La}_{0.9} \mathrm{Sr}_{0.1} \mathrm{MnO}_{3}$ air electrode. The sicctrochemical performance of the LSM material was compared to that of platinum.

- The effective reactiun length (zone) in LSM increases with an increase in temperature. Likewise the reaction zone can be modified electrochemically by applying an external potential.

- The reaction kinetics for an LSM/Z8Y interface are enhanced dramatically by an applied potential exceeding an apparent critical value.

- Apparently, dissociation of the $\mathrm{O}_{2}$ molecule into adsorbed $\mathrm{O}$ atoms near the effective reaction zone limits the reaction kinetics at the $\mathrm{La}_{0.9} \mathrm{Sr}_{0.1} \mathrm{MnO}_{3} / \mathrm{Z} 8 \mathrm{Y}$ interface.

\section{REFERENCES}

1. J.L. Bates, L.A. Chick, W.J. Weber and G.E. Youngblood, "Advanced Materials and Electrochemical Processes in High-Temperature Solid Electrolytes," in AR\&TD Fossil Energy Materials Program Semiannual Progress Report for the Period Ending March 31, 1989, ORNL/FMP/89/1, Oak Ridge National Laboratory, Oak Ridg`, TN, pp 167-182.

2. J. L. Bates, L.A. Chick, W.J. Weber and G.E. Youngblood, "Advanced Materials for HighTemperature, Solid Electrolyte Applications," in Proceedings of the Fourth Annual Conference on Fossil Energy Materials, Oak Ridge National Laboratory, Conf. 900546, ORNL/FMP-90/1, 1989, pp. 157-170.

3. J. L. Bates, L. A. Chick, G. E. Youngblood, and W. J. Weber, "Advanced Materials and Electrochemical Processes in High-Temperature Solid Electrolytes," In AR\&TD Fossil Energy Materials Program Semiannual Progress Report for the Period Ending Sept. 30, 1989, ORNL/FMP/89/2, Oak Ridge National Laboratory, Oak Ridge, TN, 149-178.

4. L.A Chick, J.L. Bates, L.R. Pederson and H.E. Kissinger, "Synthesis of Air-Sinterable Lanthanum Chromite Powders," in Proc. First International Symposium: Solid Oxide Fuel Cells, Subhash C. Singal, Ed. Electrochemical Society, Inc. Pennington, NJ, 1989, pp. 170-187.

5. H.L. Tuller and A. S. Nowick, "Doped Ceria as a Solid Oxide Electrolyte," J. Electrochem. Soc. 122 No. 2, 1975, pp. 255-259. 
6. O. Yamamoto, Y. Takeda, R. Kanno, a d M. Noda, "Perouskite-Type Oxides as Oxygen Electrodes for High Temperature Oxic e Fuel Cells, ${ }^{2}$ Solid State Ionics, 22, 1987, pp. 241-246.

7. A. Hammouche, E. Siebert, M. Kleitz, and A. Hammou, "Oxygen Reduction at the $\mathrm{La}_{1-x} \mathrm{Sr}_{\mathrm{x}} \mathrm{MnO}_{3}$ /Zirconia Electrode," in Solid Oxide Fuel Cells, Proc. of the 1st International Symposium, The Electrochemical Society Inc., 1989, pp. 265-276.

8. Y. Matsumoto, H. Yoneyama, and H. Tamura, "Influence of the Nature of the Conduction Band of Transition Metal Oxides on Catalytic Activity for Oxygen Reduction," J. Electroanal. Chem. $\underline{83}, 1977$, p. 237.

9. Y. Takeda, R. Kanno, M. Noda, Y. Tomida, and O. Yamamoto, "Cathodic Polarization Phenomena of Perovskite Oxide Electrodes with Stabilized Zirconia," J. Electrochem. Soc. 134/11, 1987, p. 2656.

10. J. Ross McDonald, Impedance Spectroscopy, Emphasizing Solid Materials and Systems, John Wiley \& Sons, New York, NY, 1987, pp. 87-95.

11. John Newman, "Resistance for Flow of Current to a Disk," J. Electrochem. Soc. May, 1966, p. 501.

12. E. J. L. Schouler, "Relation Between Solid Oxide Electrolyte Surface Properties and Electrode Reaction Kinetics," Solid State Ionics 9\&10, 1983, p. 945.

13. T. Inoue, N. Sekj, K. Eguchi, and H. Arai, "Low-Temperature Operation of Solid Electrolyte Oxygen Sensor: Using Perovskite-type Oxide Electrodes and Cathodic Reaction Kinetics," J. Electrochem Soc. 137/8, 1990, p. 2523.

14. E. J. L. Schowler and M. Kleitz, "Electrocatalysis and Inductive Etfects at the Gas/Pt/Stabllized Zirconia Interface," J. Electrochem. Soc. 134/5, 1987, p. 1045.

15. A. Hammouche, E. Siebert, and A. Hammou, "Crystallographic, Thermal and Electrochemical Properties of the System $\mathrm{La}_{1-x} \mathrm{Sr}_{\mathrm{x}} \mathrm{MnO}_{3}$ for High Temperature Solid Electrolyte Fuel Cells," Mat. Res. Bull: 24, 1989, pp. 367-380. 

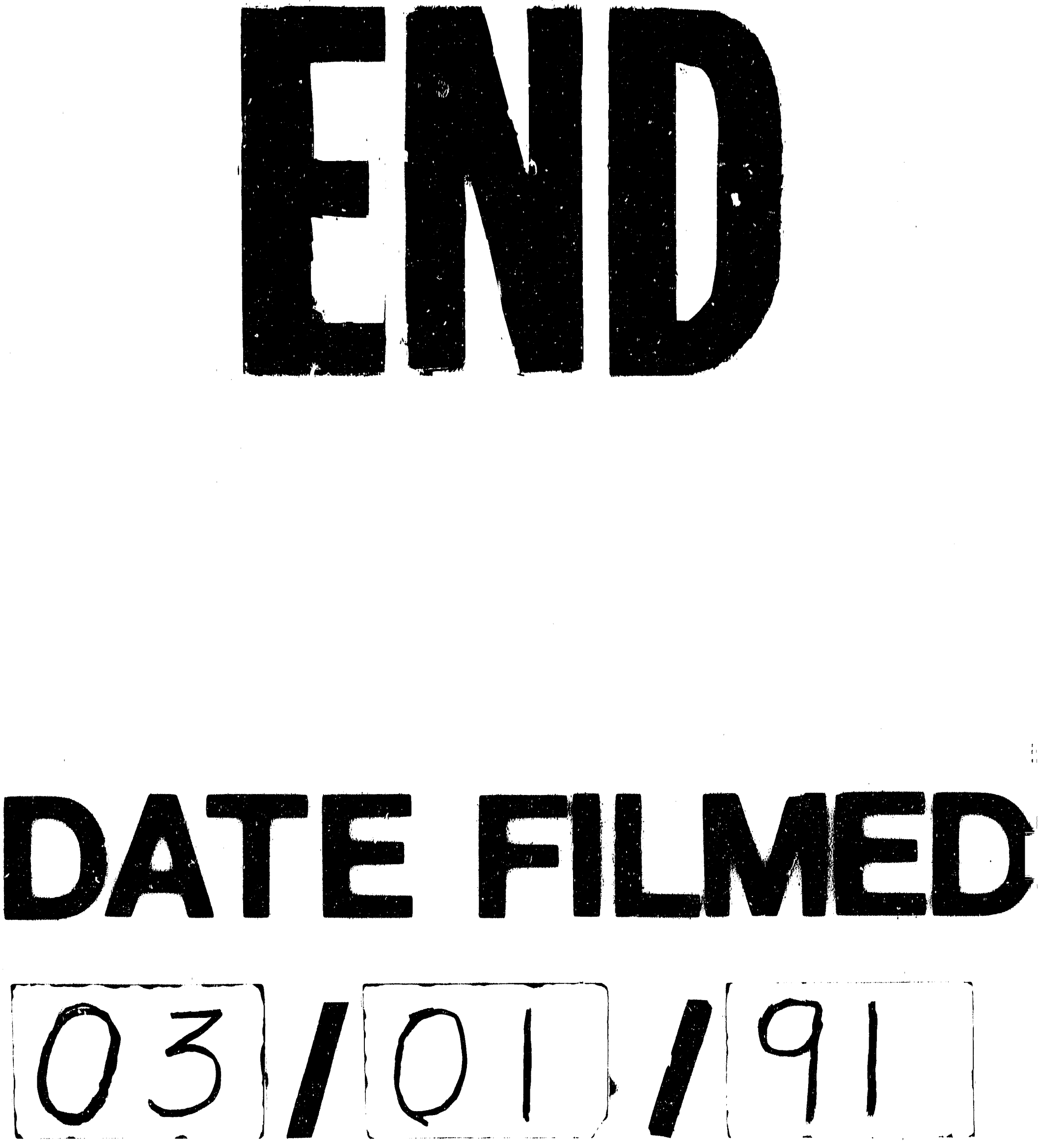
. 